\title{
Rozstrzyganie sporów w oparciu o zasady dobra i słuszności versus orzekanie w ,trudnych przypadkach" w świetle współczesnych koncepcji metaetycznych
}

\author{
Izabela Skoczeń \\ Uniwersytet Jagielloński w Krakowie \\ izabela.skoczen@uj.edu.pl
}

Otrzymano 12 grudnia 2017, zaakceptowano 21 stycznia 2018, opublikowano 26 kwietnia 2018.

\begin{abstract}
Abstrakt
W niniejszym artykule argumentuję przeciwko tezie o niemożliwości epistemicznej obiektywizacji orzekania ex aequo et bono. Najpierw dokonuję przeglądu regulacji prawnych dotyczących orzekania według tego, co słuszne i dobre. Następnie argumentuję, że decyzje podejmowane na wspomnianej podstawie orzekania nie są subiektywne z trzech głównych powodów. Po pierwsze, struktura argumentacji prowadzącej do tego rodzaju decyzji jest analogiczna do struktury argumentacji w tak zwanych "trudnych przypadkach" (ang. hard cases). Po drugie, teorie praktycznego rozumowania oraz hybrydowego ekspresywizmu dostarczają ramy teoretycznej dla tego rodzaju mechanizmów decyzyjnych. Po trzecie, kontekst argumentacyjny dostarcza istotnych ograniczeń dla dyskrecji sędziego.
\end{abstract}

Słowa kluczowe: ex aequo et bono; hybrydowy ekspresywizm; rozumowanie praktyczne; sądy etyczne; inkluzywny pozytywizm; kontekst.

\section{Wstęp}

Niniejszy tekst ma dwa główne cele. Pierwszym celem jest ukazanie podobieństw pomiędzy orzekaniem w oparciu o zasady dobra i słuszności zamiast przepisów prawnych (tak zwanym orzekaniem ex aequo et bono) oraz orzekaniem w trudnych przypadkach (ang. hard cases), czyli w takich, w których mamy do czynienia z pojęciem nieostrym lub luką w prawie. Drugim celem jest sformułowanie argumentu ukazującego, że, paradoksalnie, 
orzekanie w oparciu o zasady dobra i słuszności może w większym stopniu spełniać kryteria idealizacji, jaką jest obiektywizm w podejmowaniu decyzji, niż orzekanie w trudnych przypadkach w oparciu o system zawierający lukę.

Tekst został podzielony na cztery części. W pierwszej dokonuję enumeracji i charakteryzacji podobieństw i różnic pomiędzy orzekaniem w oparciu o zasady dobra i słuszności oraz orzekania w trudnych przypadkach. Podobieństwa dotyczyć będą występowania podważalności rozumowań (defeasibility), wad języka naturalnego czy kontrowersji wokół pojęcia obiektywności orzekania. Ponadto próbuję nakreślić powód, dla którego liczba spraw rozstrzyganych w oparciu o zasady dobra i słuszności jest znacząco niższa od liczby trudnych przypadków, rozstrzyganych w oparciu o system norm, które takiego przypadku nie dotyczą, gdyż istnieje w tym systemie luka. Powodem tym jest chybiony zarzut relatywizmu i subiektywizmu orzekania w oparciu o reguły dobra i słuszności.

W drugiej części dokonuję zwięzłego przeglądu współczesnych stanowisk metaetycznych oraz wybieram jako przedmiot dalszej analizy to stanowisko, którego celem jest walka z subiektywizmem i relatywizmem przy równoczesnej próbie spełnienia warunków, które współcześnie stawiamy teoriom metaetycznym. Bowiem to właśnie spełnienie tych warunków wyróżnia ekspresywizm spośród pozostałych dostępnych obecnie na rynku stanowisk metaetycznych. Ekspresywizm (oraz teorie neoekpresywistyczne, takie jak na przykład hybrydowy ekspresywizm) stawia sobie za cel wyjaśnienie istniejącej praktyki językowej polegającej na używaniu predykatów ocennych, oddalanie postulatów rewizjonistycznych wobec praktyki języka etycznego, wyjaśnienie uporczywej niezgody moralnej, lekkość ontologiczną (krytykę postulowania podejrzanych faktów moralnych) oraz wyjaśnienie intuicyjnie akceptowalnych rozumowań zawierających nonkognitywne przesłanki moralne. Można oczywiście spierać się o to, na ile argumenty ekspresywistów są przekonujące, oraz próbować ulepszać tę teorię lub proponować alternatywne rozwiązania, co wielu badaczy metaetyki czyni. Tym niemniej do rozważań zawartych w niniejszym tekście wystarczy sam fakt, że istnieje program badawczy, który stara się wyżej wymienione postulaty filozoficzne spełnić.

W trzeciej części dokonuję przeglądu doktrynalnych definicji orzekania w oparciu o zasady dobra i słuszności oraz staram się pokazać, że ekspresywistyczne odczytanie tych definicji powinno mitygować zarzut subiektywizmu i relatywizmu takiego orzekania. Ponadto staram się wskazać, że orzekanie w oparciu o zasady dobra i słuszności oraz w trudnych przypadkach jest podobne zarówno na gruncie metaetyki, jak i na gruncie sposobu postępowania sędziego w praktyce. Bowiem stosowanie doktryny ekspresywistycznej w praktyce będzie polegało na stosowaniu rozumowania praktycznego, kontekstowego zawężania dostępnych racji czy analizy praktyki stosowania predykatów etycznych w języku naturalnym oraz intuicji dotyczących poprawności konkretnych rozumowań zawierających predykaty moralne.

Wreszcie, w czwartej części wskazuję na teorie, które pozwalają na prowadzenie poprawnych rozumowań zawierających przesłanki normatywne. Jeżeli zarysowana w niniejszym tekście ekspresywistyczna wizja orzekania w oparciu o zasady dobra i słuszności ma być 
przekonująca, to konieczne jest wskazanie, w jaki sposób możliwe są poprawne rozumowania zawierające przesłanki normatywne. Posłużę się tutaj bardziej współczesną wersją ekspresywizmu zwaną hybrydowym ekspresywizmem oraz odpowiednikiem tej teorii na poziomie nie całego sądu logicznego, ale poszczególnych słów, czyli teorią tak zwanych thustych lub gęstych predykatów (thick terms).

\section{Orzekanie w oparciu o zasady dobra i słuszności versus orzekanie $w$ tak zwanych trudnych przypadkach}

Orzekanie w oparciu o zasady dobra i słuszności zamiast przepisów prawnych oznacza orzekanie w oparciu o racje moralne (Trakman, 2008). Tymczasem orzekanie w trudnych przypadkach, czyli takich, w których mamy do czynienia z luką w prawie (ponieważ, na przykład, ustawodawca nie przewidział, iż dany kontekst orzekania może się pojawić), również oznacza dopuszczalność argumentów zawierających racje moralne. Nawet współczesne wersje pozytywizmu (tak zwany pozytywizm inkluzywny), który w klasycznej wersji z założenia miał wykluczać racje moralne w procesie orzekania, obecnie je dopuszcza (Pichlak, 2017; Dyrda, 2013).

Rozstrzyganie trudnych przypadków (ang. hard cases) bardzo często jest efektem ważenia argumentów moralnych czy politycznych. Jest to motywowane koniecznością podjęcia decyzji w sytuacji braku uregulowań prawnych dotyczących rozważanego kontekstu. Ujmując problem w kategoriach kontynentalnych, jeśli wykładnia językowa i systemowa zawiodą, to spojrzenie funkcjonalne bardzo często odwołuje się do tego typu pozaprawnych argumentów. Dobrze ilustruje tą kwestię słynne orzeczenie z 1889 roku w sprawie Riggs versus Palmer, w którym sąd postanowił odmówić dziedziczenia zabójcy spadkodawcy, pomimo że w systemie prawa nie było przepisu, który by takiego dziedziczenia zabraniał. Sąd oparł jednak swoje rozumowanie na założeniu, iż nikt nie powinien czerpać korzyści ze swego złego uczynku¹ (Marmor, 2014). Konsekwencją takiego stanu rzeczy, w pewnym uproszczeniu, jest konieczność pogodzenia się z faktem, że całkowity rozdział prawa i moralności nie jest możliwy. Racje moralne były, są i będą elementem rozumowań sędziowskich. Teorie, które postulowały całkowity rozdział prawa i moralności w procesie stosowania prawa, pozostają cennym eksperymentem myślowym, uświadamiającym zagrożenia mogące wypływać z nadmiernego inkorporowania racji moralnych do prawa. Nie sposób jednak wskazać wśród współczesnych systemów prawnych choć jednego, który przestrzegałby całkowicie tego rozdziału w procesie stosowania prawa.

Ponadto nie każde stanowisko w filozofii prawa zakłada a priori eliminację moralnej argumentacji. Argumenty przede wszystkim moralne, w mniejszym stopniu społeczne czy polityczne, nie są odrzucane w procesie orzekania przez wspomnianych już ,inkluzywnych" pozytywistów. Takie stanowisko wręcz zakłada ich przydatność dla poprawnego i naturalnego funkcjonowania systemu prawnego. Inkluzywiści podkreślają, że tam, gdzie

\footnotetext{
${ }^{1}$ http://www.courts.state.ny.us/reporter/archives/riggs_palmer.htm [dostęp 29 maja 2015].
} 
prawo wyraźnie wskazuje, że decyzja sędziego ma być oparta o racje moralne, ich zastosowanie jest całkowicie uzasadnione (Green, 2009). Kategoryczne odrzucenie takich argumentów pozostaje domeną ekskluzywistów (Dyrda, 2013; Hart, 2012). Zatem można budować spójne teorie systemów prawnych, które inkorporują tego typu racje.

Reasumując, kontrastowanie orzekania na podstawie reguł prawa i na podstawie ex aequo et bono w oparciu o stosowanie pozaprawnych racji moralnych jest nieuzasadnione. Co więcej, występowanie predykatów moralnych w wyrażeniu ex aequo et bono nie musi oznaczać, w każdym wypadku, sięgania po argumenty stricte moralne. Możliwe jest bowiem argumentowanie w oparciu o tak zwaną pozytywną moralność, czyli pewną praktykę wykształconą w danym społeczeństwie (Green, 2009) ${ }^{2}$. Takie uzasadnienie decyzji jest już bardzo bliskie pozytywistycznemu sercu, gdyż ma swoje źródło w faktach społecznych (Green, 2009).

Ponadto przepisy proceduralne dopuszczające wybór przez strony orzekania w oparciu o zasady dobra i słuszności dotyczą spraw o złożonych kontekstach, w których prawdopodobieństwo pojawienia się trudnego przypadku jest niezwykle wysokie, czyli spraw na szczeblu międzynarodowym. Międzynarodowe akty prawne zawierają wiele częściowo ujednoliconych regulacji dotyczących zasady orzekania ex aequo et bono. Występują one zarówno w regulacjach arbitrażu prywatnego, jak i publicznego, a także na przykład w statucie Międzynarodowego Trybunału Sprawiedliwości (MTS).

Ex aequo et bono to elastyczna podstawa orzekania, stosowana ponad granicami podziałów metod regulacji prawnych w zależności od udziału czynnika państwowego. Analizę rozpocznę od przepisów arbitrażu komercyjnego. Artykuł dwudziesty pierwszy Regulaminu Arbitrażowego Międzynarodowej Izy Handlu (ICC) otrzymał następujący kształt:

1) Strony mają swobodę wyboru prawa stosowanego przez trybunał arbitrażowy w odniesieniu do istoty sporu. W przypadku braku takiego wyboru, trybunał arbitrażowy zastosuje prawo, które uzna za właściwe.

2) Trybunał arbitrażowy bierze pod uwagę postanowienia umowy pomiędzy stronami oraz odnośne zwyczaje handlowe.

3) Trybunał arbitrażowy będzie uprawniony do działania jako amiable compositeur lub decydowania ex equo et bono tylko wtedy, jeżeli strony zgodziły się na przyznanie mu takich uprawnień. (Regulamin Arbitrażowy Międzynarodowej Izby Handlowej, 2017, art. 21)

Artykuł drugi, punkt trzeci wyraźnie wskazuje, że wybór takiego orzekania musi być decyzją stron. Doktryna oraz praktyka przyjmuje, że zgoda musi mieć wyraźny charakter. Niedopuszczalne jest domniemanie zgody stron co do orzekania w oparciu o ex aequo et bono. Co więcej, niemożliwe jest autonomiczne wyrażenie zgody na takie postepowanie przez sam panel arbitrów bez zgody stron. Zatem taka podstawa orzekania jest postrzegana jako wyjątek albo dodatek do wyboru prawa właściwego (Trakman, 2008).

\footnotetext{
2 "positive morality, i.e. to the moral customs actually practiced by a given society, and no one denies that positive morality may be a source of law" (Green, 2009).
} 
Z kolei artykuł dwudziesty szósty Europejskiej Konwencji o Pokojowym Rozstrzyganiu Sporów, podpisanej w Strasburgu 29 kwietnia 1957 roku, stanowi:

Jeżeli strony nie postanowią inaczej, Trybunał może orzekać ex aequo et bono, mając na uwadze ogólne zasady prawa międzynarodowego oraz szanując umowne zobowiązania stron i ostateczne decyzje trybunałów międzynarodowych, które są dla stron wiążące. (European Convention for the Peaceful Settlement of Disputes, 1957, art. 26; thumaczenie moje) ${ }^{3}$

Powyższy przepis explicite wskazuje, że ramy omawianego orzekania są ściśle ograniczone. Mianowicie podjęta decyzja, nie może pozostawać w sprzeczności z ogólnymi zasadami prawa międzynarodowego, zobowiązaniami stron podjętymi na podstawie umów czy ostatecznymi decyzjami trybunałów międzynarodowych, które wiążą strony. Taki katalog ograniczeń wydaje się wystarczająco szeroki, aby zagwarantować spójność podjętej decyzji z resztą porządków prawnych, w których będzie ona funkcjonować. W takich granicach władza arbitrów pozostaje nieograniczona. Nie oznacza to jednak zupełnej dowolności, co postaram się wykazać w pozostałej części niniejszego tekstu.

Podobne restrykcje zawiera artykuł 33 regulaminu arbitrażowego redagowanego przez Komisję Narodów Zjednoczonych do spraw Międzynarodowego Prawa Handlowego (UNCITRAL):

1. Trybunał powinien stosować prawo materialne wskazane przez strony. Jeżeli strony nie wskażą preferowanego prawa, trybunał zastosuje prawo wynikające z reguł kolizyjnych, które uzna za właściwe.

2. Trybunał orzeka jako amiable compositeur lub ex aequo et bono tylko za wyraźną zgodą stron oraz jeżeli procedura arbitrażowa na to pozwala.

3. W każdym przypadku trybunał powinien decydować $\mathrm{w}$ zgodzie $\mathrm{z}$ postanowieniami umowy oraz powinien brać pod uwagę zwyczaje handlowe mające zastosowanie do transakcji. (UNCITRAL Arbitration Rules, 2013, art. 33; thumaczenie moje) ${ }^{4}$

Analogicznie do artykułu 26 wyżej wspomnianej konwencji, regulamin UNCITRAL ogranicza dyskrecję arbitrów, próbując zagwarantować spójność podjętej decyzji z porządkami normatywnymi, w których ma ona docelowo funkcjonować.

\footnotetext{
3 "If nothing is laid down in the special agreement or no special agreement has been made, the Tribunal shall decide ex aequo et bono, having regard to the general principles of international law, while respecting the contractual obligations and the final decisions of international tribunals which are binding on the parties."

${ }^{4} 1$. The arbitral tribunal shall apply the law designated by the parties as applicable to the substance of the dispute. Failing such designation by the parties, the arbitral tribunal shall apply the law determined by the conflict of laws rules which it considers applicable.

2. The arbitral tribunal shall decide as amiable compositeur or ex aequo et bono only if the parties have expressly authorised the arbitral tribunal to do so and if the law applicable to the arbitral procedure permits such arbitration.

3. In all cases, the arbitral tribunal shall decide in accordance with the terms of the contract and shall take into account the usages of the trade applicable to the transaction."
} 
Orzekanie ex aequo et bono jest także możliwe w ramach procedur arbitrażowych, w których obecny jest element publiczno-prawny. Artykuł czterdziesty drugi konwencji Międzynarodowego Centrum Rozstrzygania Sporów Inwestycyjnych (ICSID) stanowi:

1. Trybunał rozstrzyga spory na podstawie prawa wybranego przez strony. W przypadku braku takiego wyboru, trybunał zastosuje prawo państwa-strony (także jego reguły kolizyjne) oraz reguły prawa międzynarodowego, które znajdują zastosowanie.

2. Trybunał nie może orzec non-liquet na podstawie milczenia lub niejasności prawa.

3. Punkty 1 i 2 nie pozbawiają trybunału mocy orzekania ex aequo et bono, jeśli strony wyrażą na to zgodę. (Convention on the Settlement of Investment Disputes between States and Nationals of Other States, 1965, art. 42; thumaczenie moje) $)^{5}$

Regulacja ICSID jest tym bardziej intrygująca, że dopuszcza możliwość wyrażenia przez strony zgody na orzekanie ex aequo et bono, nawet jeśli trybunał już rozpoczął procedowanie na podstawie reguł właściwego prawa. Jest to zatem wyraźny sygnał normodawcy, że uważa taką możliwość za cenną i maksymalnie liberalizuje reguły jej zastosowania (Trakman, 2008).

Co więcej, możliwość orzekania w oparciu o ex aequo et bono zawiera statut najbardziej wyeksponowanego na arenie międzynarodowej organu Organizacji Narodów Zjednoczonych, jakim jest Międzynarodowy Trybunał Sprawiedliwości (MTS). Artykuł 38 Statutu MTS otrzymał następujący kształt:

1. Trybunał, którego zadaniem jest orzekać na podstawie prawa międzynarodowego w sporach, które będą mu przekazane, będzie stosował:

a) konwencje międzynarodowe, bądź ogólne, bądź specjalne, ustalające reguły, wyraźnie uznane przez państwa spór wiodące;

b) zwyczaj międzynarodowy, jako dowód istnienia powszechnej praktyki, przyjętej jako prawo;

c) zasady ogólne prawa, uznane przez narody cywilizowane;

d) z zastrzeżeniem postanowień artykułu 59, wyroki sądowe tudzież zdania najznakomitszych znawców prawa publicznego różnych narodów, jako środek pomocniczy do stwierdzania przepisów prawnych.

2. Postanowienie niniejsze nie stanowi przeszkody, aby Trybunał mógł orzekać ex aequo et bono, o ile strony się na to zgadzają. (Statut Międzynarodowego Trybunału Sprawiedliwości, 1945, art. 38)

\footnotetext{
5 " (1) The Tribunal shall decide a dispute in accordance with such rules of law as may be agreed by the parties. In the absence of such agreement, the Tribunal shall apply the law of the Contracting State party to the dispute (including its rules on the conflict of laws) and such rules of international law as may be applicable.

(2) The Tribunal may not bring in a finding of non liquet on the ground of silence or obscurity of the law.

(3) The provisions of paragraphs (1) and (2) shall not prejudice the power of the Tribunal to decide a dispute ex aequo et bono if the parties so agree."
} 
Z punktu widzenia niniejszych rozważań interesujący jest punkt drugi. Co ciekawe, MTS nigdy jeszcze nie orzekał wyłącznie na tej podstawie. Była ona stosowana jedynie pomocniczo $\mathrm{w}$ połączeniu $\mathrm{z}$ innymi podstawami orzekania.

Lista podobieństw pomiędzy orzekaniem w oparciu o zasady dobra i słuszności oraz orzekaniem w trudnych przypadkach nie wyczerpuje się na stosowaniu racji moralnych czy złożoności kontekstu orzekania. Kolejnym podobieństwem jest podważalny charakter zarówno rozumowań zawierających racje prawne, jak i rozumowań zawierających racje moralne. Bowiem rozumowania prawnicze oraz moralne nie mają charakteru monotonicznego. Innymi słowy, jeżeli pewna konkluzja wynika z, powiedzmy, trzech przesłanek, to po dodaniu dodatkowej przesłanki (na przykład na podstawie kontekstu) może się okazać, że konkluzja nie jest już uprawniona (Brożek, 2008).

Rozważmy klasyczny przykład:

(I) Pojazdy mechaniczne nie mogą wjeżdżać do parku.

PM jest pojazdem mechanicznym.

PM nie może wjechać do parku.

Jeżeli jednak okaże się, że PM jest karetką pogotowia, to konkluzja nie będzie już wynikać z przesłanek (Marmor, 2016). Ponadto nie jest istotne, czy pierwsza przesłanka rozumowania (I) jest racją prawną czy moralną, zjawisko podważalności stosuje się do obu niezależnie.

Kolejnym podobieństwem pomiędzy dwoma podstawami orzekania jest fakt, iż przesłanki normatywne, czy to moralne, czy stricte prawne, wyrażamy w języku naturalnym (ewentualnie $\mathrm{w}$ jego specjalnym rejestrze). W konsekwencji w obu przypadkach sędzia musi stawić czoła niedoskonałościom języka naturalnego. Lista niedoskonałości jest długa, a ich dokładna charakteryzacja przekraczałaby skromne ramy niniejszego tekstu, dlatego ograniczę się do wskazania zaledwie kilku z nich. Przede wszystkim zarówno pojęcia moralne, jak i pojęcia języka prawnego (na przykład pojęcia zawarte w klauzulach generalnych) bywają nieostre, a zatem nie zawsze możemy orzec, czy w danym kontekście można posłużyć się danym pojęciem. Jako przykład można wskazać pojęcia dobra, słuszności, sprawiedliwości, równości itp. Po drugie, źródłem problemów interpretacyjnych są również pojęcia otwarte, czyli takie, które nie pozwalają na wyczerpujące sformułowanie kryteriów ich użycia (Wronkowska, Zieliński, 1985). Metaetycy określają ten problem jako argument z otwartego pytania, który nakreślę w pewnym uproszczeniu (Hurka, 2015; Moore, 2004). Rozważmy otwartość pojęcia „dobro”: nawet jeżeli ustalimy pewne kryteria użycia tego pojęcia, to wciąż możliwe będzie postawienie pytania „czy to jest dobre?” wobec nowego, wcześniej nierozważanego kontekstu. Zatem pojęcia otwarte czynią niemożliwym wyczerpującą enumerację kryteriów ich zastosowania. Takie pojęcia występują zarówno w dyskursie prawnym, jak i moralnym. Po trzecie, takie zjawiska jak wieloznaczność (oraz jej rodzaje, takie jak na przykład polisemia [Marmor, 2014]), otwarta tekstowość, nieadekwatność literalnego znaczenia itp. powodują, że podobne problemy pojawiają się w rozumowaniach opartych zarówno na przesłankach moralnych, jak i prawnych (Wronkowska, Zieliński, 1985). 
Wreszcie, panuje powszechne przekonanie, że orzekanie w oparciu o zasady dobra i słuszności zwiększa prawdopodobieństwo subiektywistycznego czy relatywistycznego orzekania w oparciu o, niepodzielane powszechnie, przekonania sędziego. Orzekanie ex aequo et bono kontrastuje się $\mathrm{z}$ orzekaniem $\mathrm{w}$ trudnych przypadkach $\mathrm{w}$ oparciu o przepisy prawne jako orzekaniem spełniającym wymóg obiektywizmu, nie wyróżniając sytuacji, w której mamy do czynienia z luką. Tymczasem pojęcie obiektywizmu orzekania jest problematyczne również na gruncie orzekania w oparciu o przepisy prawne, co powoduje, że argument o subiektywizmie orzekania ex aequo et bono wydaje się pozbawiony podstaw teoretycznych. Jak argumentuje T. Gizbert-Studnicki, samo pojęcie obiektywności orzekania nie może być pojęciem tożsamym z obiektywnością naukową, która jest w pełni niezależna od naszych przekonań. Obiektywność orzekania jest powiązana z powszechną akceptacją pewnych przekonań czy nastawień propozycjonalnych (Gizbert-Studnicki, 2012). Zatem cechy obiektywności przypisujemy nie obiektom (tak jak w przypadku obiektywności ontologicznej), tylko zdaniom lub przekonaniom, i dlatego obiektywność orzekania ma charakter epistemiczny (Gizbert-Studnicki, 2012). Co więcej, nie wszystkim zdaniom dotyczącym moralności czy prawa można przypisać wartość prawdy lub fałszu (wrócę do tego zagadnienia w ostatniej części niniejszego tekstu). Obiektywność epistemiczna, w pewnym uproszczeniu, jest rozumiana jako oparcie decyzji na racjach zrozumiałych i przekonujących dla wszystkich. Oczywiście trudności nastręcza określenie kim są „wszyscy”. Tym niemniej przytoczona definicja jest wystarczająca do zidentyfikowania w niej elementu normatywnego obiektywizmu epistemicznego. Bowiem wymaga ona przyjęcia pewnego ideału racjonalności, rozumienia i perswazji określonego audytorium oraz ideału kontekstu (Gizbert-Studnicki, 2012). Innymi słowy, całkowite spełnienie idealizacyjnych kryteriów obiektywności epistemicznej jest w praktyce bardzo trudne lub niemożliwe, a to, że argumentacja jest przekonująca, w praktyce nie implikuje, że jest obiektywna epistemicznie (Gizbert-Studnicki, 2012).

Zatem to, że argumentacja przy rozstrzyganiu trudnego przypadku na podstawie systemu prawnego zawierającego lukę jest bardziej przekonująca w praktyce niż argumentacja w oparciu o zasady dobra i słuszności - co pokazuje znacząco większa ilość spraw rozstrzyganych w oparciu o pierwszą metodę orzekania w porównaniu z drugą - nie znajduje oparcia w większej obiektywności epistemicznej pierwszej metody w stosunku do drugiej. Przypisanie cechy obiektywności epistemicznej obu metodom jest równie wątpliwe.

Podsumowując dotychczasowe rozważania, problemy, jakie rodzi orzekanie na podstawie zasad dobra i słuszności oraz orzekanie w trudnych przypadkach na podstawie przepisów prawnych nieznajdujących bezpośredniego zastosowania w danej sprawie, są podobne. Po pierwsze, obie metody włączają do argumentacji racje moralne. Po drugie, obie metody stosowane są w kontekstach o wysokim stopniu złożoności. Po trzecie, zarówno argumentacje oparte na szeroko rozumianych racjach prawnych, jak i argumentacje oparte na racjach moralnych są równie narażone na zjawisko podważalności (defeasibility). Zarówno pojęcia moralne, jak i prawne bywają nieostre czy otwarte, a przesłanki dyskutowanych sposobów orzekania są wyrażone w języku naturalnym, co powoduje, ze dziedziczą 
wszystkie niedoskonałości tego narzędzia. Wreszcie, to, że argumentacja w trudnym przypadku oparta o system prawny zawierający lukę jest praktycznie bardziej przekonująca dla danego audytorium, nie oznacza, że jest bardziej epistemicznie obiektywna niż argumentacja oparta na zasadach dobra i słuszności.

W świetle powyższych rozważań trudna do zrozumienia jest ilościowa różnica pomiędzy sprawami rozstrzyganymi w oparciu o ex aequo et bono oraz trudnymi przypadkami rozstrzyganymi w oparciu o przepisy prawne. Przyczyna zatem musi tkwić w różnicy jakościowej dwóch metod (o ile taka różnica istnieje). Podstawowa teoretyczna różnica pomiędzy dwoma omawianymi metodami orzekania tkwi w odmiennym charakterze pierwszej przesłanki stosowanego sylogistycznego rozumowania. W przypadku orzekania w oparciu o zasady dobra i słuszności nie jest to uchwalona norma prawna, ale norma moralna, co rodzi podejrzenie subiektywności i relatywności rozstrzygnięcia. Tymczasem, jak wspomniałam wyżej, to, że pierwsza przesłanka wywiedziona jest z przepisu prawnego, nie gwarantuje obiektywności epistemicznej argumentacji. Co najwyżej może przesądzić o jej większym faktycznym czy praktycznym sukcesie dyskursywnym, co nie znajduje podstaw teoretycznych. Ponadto w trudnych przypadkach, w których system prawny zawiera lukę, pierwsza przesłanka subsumpcji jest wywodzona za pomocą wyrafinowanej gimnastyki, czy wręcz ekwilibrystyki interpretacyjnej z norm, które nie były projektowane do bycia zastosowanymi w takich sytuacjach w zamyśle legislatora. Innymi słowy, tak jak zostało wspomniane wyżej, taka pierwsza przesłanka sylogizmu może de facto redukować się do pewnej racji moralnej. Zatem najbardziej prawdopodobną hipotezą wyjaśniającą mniejszą ilość spraw rozstrzyganych w oparciu o ex aequo et bono jest raczej brak powszechnej znajomości teorii metaetycznej, która programowo walczyłaby z subiektywizmem i relatywizmem doboru pierwszej przesłanki sylogizmu. Oczywiście taka teoria nie zagwarantuje przejścia od praktycznej efektywności argumentacji do epistemicznej obiektywności, ale dostarczy podstaw teoretycznych dla prowadzenia takich rozumowań. W kolejnej części pracy dokonam zwięzłego przeglądu teorii metaetycznych w poszukiwaniu odpowiedniej teorii dla podjęcia wyzwania walki z subiektywizmem epistemicznym.

\section{Ekspresywizm jako stanowisko metaetyczne walczące $z$ relatywizmem i subiektywizmem}

Współczesna mapa teorii metaetycznych jest wysoce złożona. Trudno bowiem przeprowadzać jednoznaczne linie demarkacyjne pomiędzy teoriami, których postulaty są zawsze częściowo zbieżne. Historycznie rzecz ujmując, klasyfikacje były przeprowadzane w oparciu o rozróżnienie na teorie realistyczne (czyli wskazujące na istnienie uprawdziwiaczy sądów moralnych w świecie, na przykład faktów moralnych) i kognitywistyczne (czyli przypisujące sądom moralnym wartość prawdy lub fałszu) przeciwstawiane teoriom antyrealistycznym i nonkognitywistycznym (van Roojen, 2016). Tymczasem pojawiły się teorie łamiące tę dychotomię, na przykład teorie antyrealistyczne i kognitywistyczne oraz wersje inferencjalizmu, deflacjonizmu i minimalizmu, które przypisują wartość prawdy zdaniom funkcjonującym jako przesłanki poprawnych rozumowań w danym dyskursie 
niezależnie od ewentualnej korespondencji (lub jej braku) ze stanem świata (Dreier, 2004; Jackson et al., 1994; Smith, 1994, Posłajko 2017). Można także być zwolennikiem teorii błędu i uważać, że wszystkie zdania moralne są po prostu fałszywe (van Roojen, 2016). Z powyższych powodów skupię się na teoriach nonkognitywistycznych jako tych, które można lepiej wydzielić na mapie stanowisk metaetycznych od teorii kognitywistycznych, ponieważ nonkognitywizm wciąż łączy się z antyrealistycznym podejściem do etyki.

Pierwszym (nie chronologicznie, ale konceptualnie) stanowiskiem nonkognitywistycznym jest emotywizm. Emotywiści, w pewnym uproszczeniu, twierdzą, że wypowiadając zdania zawierające pojęcia etyczne, wyrażamy pewne - pozytywne lub negatywne - nastawienia. Zatem zdania to konwencjonalne narzędzia do wyrażania nastawień. Co więcej, wypowiadając szczerze takie zdanie, dokonujemy aktu mowy (w rozumieniu Austina), dzięki któremu potwierdzamy, że mamy dane nastawienie i wskazujemy, że życzylibyśmy sobie, aby inni również takie nastawienie mieli. Klasyczny emotywizm spotkał się z krytycznym spojrzeniem ekspresywistów, którzy wskazali na trudności w wyjaśnieniu uporczywej moralnej niezgody w pewnych kwestiach na gruncie tez wyłącznie emotywistycznych. Bowiem jeżeli spieramy się w pewnej kwestii moralnej i każdy z nas za pomocą wypowiadanych zdań jedynie wyraża swoje nastawienie, to istnieje ryzyko, że nigdy nie mówimy o tym samym (Stoljar, 1993).

Kolejnym możliwym stanowiskiem nonkognitywistycznym jest preskryptywizm, który głosi, że wypowiadając zdania dotyczące moralności, tak naprawdę wypowiadamy rozkazy. Zatem nasze wypowiedzi to także akty mowy, ściślej rzecz ujmując - imperatywy. Jednak aby skutecznie dokonać aktu mowy w sensie Austina, należy żywić odpowiednią intencję (ewentualnie nastawienie). Równocześnie jednak preskryptywiści chcieliby uniknąć wyżej wspomnianego zarzutu niemożliwości wyjaśnienia niezgody moralnej, a wydaje się to trudne na gruncie tezy o subiektywności intencji (Hare, 2003).

Trzecim stanowiskiem nonkognitywistycznym jest quasi-realizm. Punktem wyjścia tej teorii jest połączenie antyrealistycznego podejścia do etyki oraz obserwacji, że ludzie posługują się językiem naturalnym tak, jak gdyby etyka była realistyczna. Codzienny dyskurs i rozumowania moralne zdają się zakładać realizm metaetyczny. Stąd celem quasi-realistów jest wyjaśnienie dyskursu moralnego bez odwoływania się do „głębokiej” natury moralności, która może być postrzegana antyrealistycznie. Takie rozwiązania stoją jednak w sprzeczności ze standardowymi intuicjami dotyczącymi dyskursu moralnego - nie ma to być powierzchowny czy obłudny dyskurs, ale dyskurs o właściwej moralności (Blackburn, 1993).

Stanowiskiem metaetycznym, które jest obecnie szeroko dyskutowane (w formach zmodyfikowanych w stosunku do pierwotnej wersji), jest ekspresywizm. Klasyczny ekspresywizm to bardziej wyrafinowana forma emotywizmu. Ekspresywiści głoszą, że nastawienia możemy konwencjonalnie wyrażać nie tylko za pomocą zdań, ale także okrzyków czy zachowań nieustrukturyzowanych w formę zdań, takich jak na przykład „hurra!”. Ponadto ekspresywizm zwalcza subiektywizm poprzez tezę, iż wyrażając nastawienia, równocześnie sygnalizujemy, że wyrażane nastawienie jest tym właściwym w danej sytuacji. Zatem niezgoda moralna to pełnokrwisty spór o to, jakie nastawienie należy wyrazić w danym 
kontekście (Blackburn, 2011). Oczywiście, ekspresywizm, tak jak pozostałe stanowiska, jest również narażony na krytykę. Po pierwsze, nie jest jasne, czym miałaby być owa tajemnicza relacja wyrażania. O ile relacja orzekania sądów i ich oceny pod względem prawdy czy fałszu została w filozofii analitycznej poddana szczegółowej analizie, o tyle takiej analizy dla wyrażania brakuje. Ponadto ekspresywizm postuluje specyficzną semantykę zdań moralnych, gdyż sądom rekonstruowanym ze zdań nie można przypisać wartości prawdy lub fałszu. Takie ujęcie rodzi problemy w wyjaśnieniu rozumowań, w których używamy mieszanych przesłanek. Rozważmy przykład:

(I) Kłamstwo jest złe.

(II) Jan kłamie.

(III) Jan postępuje źle.

Intuicyjnie powyższe rozumowanie wydaje się być poprawne. Tymczasem klasyczny ekspresywista musi przyznać, że pierwsza przesłanka nie może być oceniania w kategoriach prawdy lub fałszu, natomiast druga może. Zatem wyjaśnienie poprawności powyższego rozumowania na gruncie klasycznego ekspresywizmu jest problematyczne (Fletcher, 2014). W odpowiedzi na ten problem powstał hybrydowy ekspresywizm, który przedstawię w ostatniej części tej pracy.

Ekspresywizm jako program metaetyczny ma wiele zalet, które powodują, że może stać się wartościową podstawą teoretyczną orzekania w oparciu o zasady dobra i słuszności. Po pierwsze, ekspresywizm wyjaśnia praktykę dyskursu moralnego bez proponowania rewizjonistycznych postulatów. Po drugie, dostarcza wyjaśnienia uporczywej niezgody moralnej. Po trzecie, jest to teoria lekka ontologicznie, która poza relacją wyrażania nie postuluje metafizycznie podejrzanych faktów moralnych istniejących w świecie. Przejdźmy zatem do próby ekspresywistycznego odczytania doktrynalnych definicji orzekania w oparciu o zasady dobra i słuszności jako odczytania pozwalającego na odparcie zarzutów subiektywizmu i relatywizmu takiego orzekania.

\section{Orzekanie ex aequo et bono w praktyce}

Program klasycznego ekspresywizmu pozwala żywić nadzieję, że obiektywność epistemiczna orzekania ex aequo et bono czy orzekania w trudnych przypadkach jest konceptualnie możliwa. Innymi słowy, warto spierać się o to, jakie nastawienia należy wyrazić w danej sytuacji, gdyż efektem sporu może być identyfikacja właściwego nastawienia. Niestety ten fakt dalej nie gwarantuje, że praktycznie skuteczna argumentacja czy rozstrzygnięcie będzie obiektywne epistemicznie. To jednak nie oznacza, że skuteczne czy przekonujące rozstrzygnięcia opierają się na całkowitej dowolności doboru pierwszej przesłanki sylogizmu zawierającej zdanie o moralności. 
Jeśli bowiem, jak sugeruje na przykład Trakman, orzekanie w oparciu o zasady dobra i słuszności ma charakter rozumowania praktycznego, to jest to kategoria dobrze zdefiniowana na gruncie filozoficznoprawnym (Trakman, 2008). Polega ona na doborze odpowiednich racji spośród palety praktycznych możliwości ${ }^{6}$. Standford Encyclopedia of Philosophy podaje następującą definicję rozumowania praktycznego:

Rozum praktyczny to ogólna umiejętność ludzka, aby ważyć racje za tym, co powinno się czynić. Takie rozważanie jest praktyczne pod co najmniej dwoma względami. Po pierwsze, jego przedmiot jest praktyczny, ponieważ jest związany z działaniem. Po drugie, jest praktyczny w swoich konsekwencjach, ponieważ refleksja na temat działania jest tym, co sprawia, że ludzie działają. (Wallace, 2014; thumaczenie moje) ${ }^{7}$

Czynniki kontekstowe w drastyczny sposób zawężają paletę możliwych racji praktycznych. Wybór pomiędzy kontekstowo wyselekcjonowanymi racjami jest już kwestią dyskrecji arbitrów. Dyskrecja taka nie oznacza jednak całkowitej dowolności, a jedynie możliwość wyboru z istotnie zawężonej liczby racji. Zatem arbiter musi w ramach pewnego kontekstu orzec, co będzie słuszne i dobre dla obu stron, na podstawie obranych praktycznych racji. Racji, które są najodpowiedniejsze z punktu widzenia pewnych kryteriów i które są podzielane przez strony. Trakman (2008) ujmuje ten proces jako sukcesję następujących etapów:

Tym, co kieruje decydowaniem na podstawie ex aequo et bono, jest potrzeba: (i) oceny sytuacji w świetle kontekstu relacyjnego, a nie in abstracto; (ii) stworzenie słusznego i sprawiedliwego rozwiązania dla obu stron; (iii) wzięcie pod uwagę szerszego kontekstu konwencyjnego oraz zwyczajów i praktyk stron; (iv) sprawne podjęcie decyzji; (v) dotarcie do transparentnych wyników, które w bezstronny sposób regulują sytuację stron. (s. 640; thumaczenie moje $)^{8}$

Orzekanie na podstawie ex aequo et bono ma zatem usystematyzowany charakter. Po pierwsze, decydent musi dokonać szczegółowej analizy kontekstu orzekania. Po drugie, za pomocą rozumowania praktycznego powinien dotrzeć do relewantnych racji, które stworzą dobre rozwiązanie (Rodriguez-Blanco, 2014). Wreszcie, musi on zagwarantować spójność rozwiązania z pozostałą częścią systemu prawnego.

\footnotetext{
6 "the decision-maker is bound neither to apply nor to disregard the law as a matter of principle, but to exercise discriminating judgment on the practical reasons by which to decide each case.” (Trakman, 2008, s. 640)

7 "Practical reason is the general human capacity for resolving, through reflection, the question of what one is to do. Deliberation of this kind is practical in at least two senses. First, it is practical in its subject matter, insofar as it is concerned with action. But it is also practical in its consequences or its issue, insofar as reflection about action itself directly moves people to act."

8 "Guiding the application of ex aequo et bono decision-making is the need: (i) to evaluate it in light of each relational context and not in the abstract; (ii) to encompass within it "fairness" between the parties in their circumstances; (iii) to embody in relation to the parties an assessment of the wider context of conventions, customs and usages, including legal usages that impinge upon the practices of those parties; (iv) to engage in an expeditious process of decision-making; and (v) to arrive at results that are transparent and evenhanded in their treatment of the parties."
} 
Elementem, który może wydawać się niedookreślony poprzez swój dyskrecjonalny charakter, jest dobór praktycznej racji, która przesądzi o takim a nie innym kształcie decyzji. Innymi słowy, niejasne może pozostawać, w świetle powyższych rozważań, w jaki sposób decydent określi, co jest sprawiedliwe i dobre w danej sytuacji. Na gruncie filozoficznym ilustruje to proces obierania konkretnego nastawienia (w ekspresywistycznym rozumieniu) wobec użycia predykatu moralnego. Ponadto praktyka językowa stosowanych rozumowań moralnych, które są postrzegane jako intuicyjnie prawdziwe, jest kolejnym czynnikiem zawężającym paletę nastawień, które można wyrazić w danym kontekście. Jak już zostało wspomniane, możliwe jest argumentowanie w oparciu o tak zwaną pozytywną moralność, czyli pewną praktykę wykształconą w danym społeczeństwie (Green, 2009).

Tymczasem na gruncie powyższych teorii rozumowania praktycznego wciąż niejasna pozostaje kwestia, dlaczego poniższe rozumowanie jest intuicyjnie prawdziwe:

(I) Kłamstwo jest złe.

(II) Jan kłamie.

(III) Jan postępuje źle.

Skoro nastawienia nie mogą być oceniane w kategoriach prawdy lub fałszu, niejasne pozostaje, dlaczego takie rozumowania jak powyżej nazywamy w dyskursie moralnym „prawdziwymi”. Przyjrzyjmy się teraz tej kwestii.

\section{Pojęcia thuste oraz hybrydowy ekspresywizm}

Regulacje prawne nie zawierają definicji orzekania ex aequo et bono. Można ją znaleźć w słownikach pojęć prawnych. Black's Law Dictionary definiuje to jako orzekanie „W sprawiedliwości i uczciwości; zgodnie z tym, co słuszne i dobre; zgodnie z równością i racjonalnością" (1990, s. 557; tłumaczenie moje $)^{9}$.

$\mathrm{Na}$ gruncie filozofii języka oraz metaetyki interesującym zjawiskiem pozostaje występowanie takich wyrażeń wartościujących jak: „sprawiedliwy”, „uczciwy”, „słuszny”, „dobry”, „równy”, ,racjonalny”, ,zły”, „,niesłuszny”, „,bezstronny”, „odważny”, „,tchórzliwy” itd. Wyrażenia takie mają bądź to hybrydowy charakter (są deskryptywno-wartościujące), bądź czysto wartościujący ${ }^{10}$. Pierwsze z nich, o hybrydowej strukturze, są określane w literaturze jako tak zwane „thuste pojęcia” (thick terms; Kirchin, 2013). Popularnym przykładem takiego wyrażenia jest „odważny”, który łączy w sobie deskrypcję, czyli opis zachowania wymagającego pokonania strachu, i ewaluację, czyli pozytywne wartościowanie danego zachowania. Pojęcie „dobry” z kolei wydaje się mieć o tyle jednolity charakter,

\footnotetext{
9 "in justice and fairness; according to what is just and good; according to equity and conscience" (s. 557, $6^{\text {th }}$ edition 1990). Z kolei edycja ósma z 2004 zawiera częściowo inną definicję: ,,ex aequo et bono [Latin] According to what is equitable and good. A decision-maker (esp. in international law) who is authorized to decide ex aequo et bono is not bound by legal rules and may instead follow equitable principles [...]".

${ }^{10}$ Takie wyrażenia mogłyby również mieć jedynie opisowy charakter, byłoby to jednak stanowisko skrajnie subiektywistyczne, a zatem mało interesujące z punktu widzenia filozoficznego, ponieważ oznaczałoby to trudność w wyjaśnieniu istoty sporów moralnych.
} 
o ile jego głównym składnikiem jest pozytywne nastawienie (ang. attitude). Takie pojęcia są w literaturze określane mianem ,pojęć chudych” (thin terms; Kirchin, 2013). Zawartość „nastawieniowa” czy wartościująca wyrażeń języka naturalnego budzi wiele kontrowersji. Kluczową kwestią jest rozstrzygnięcie, czy jest ona częścią semantyki języka (konwencjonalnego znaczenia słów), czy raczej jego pragmatyki (kontekstowo zależnej zawartości). Taka kontrowersja wynika przede wszystkim z innego spornego zagadnienia: czy treść wartościująca może być postrzegana w kategoriach prawdy lub fałszu. Innymi słowy, czy używając pojęć moralnych jedynie przytaczamy, czy też wyrażamy nasze nastawienia wartościujące wobec konkretnego zjawiska, które komentujemy. Jeżeli przytaczamy te nastawienia, to nasze mówienie ma charakter sprawozdawczy i jest jak najbardziej możliwe do oceny w kategoriach prawdy czy fałszu. Wszak zawsze możemy kłamać (Jackson, Petit, 1998). Jednak wtedy problem polega na tym, że popadamy w subiektywizm i nie możemy prowadzić sporów moralnych, ponieważ każdy spiera się w kwestii innego nastawienia swojego własnego - i nigdy nie dyskutujemy o tym samym. Natomiast jeśli nasze działanie lingwistyczne jedynie wyraża nastawienia, to trudno je oceniać w kategoriach prawdy lub fałszu. Spora część badaczy opowiada się za drugą propozycją - dlatego pojawia się szereg pytań. Jeżeli jedynie wyrażamy nastawienia, to jak to jest możliwe, że za pomocą jednego wyrażenia językowego (użytego w zdaniu) przekazujemy częściowo zawartość deskrypywną, a częściowo ewaluatywną? Innymi słowy, czy powstaje sąd, który tylko częściowo może być oceniany w kategoriach prawdy lub fałszu? Czy zatem posługujemy się dwoma różnymi semantykami? Niekoniecznie. Jeżeli bowiem zawartość wartościująca wyrażeń językowych (nastawienia) i przypisanych im pojęć oraz ewentualnie własności (na przykład posiadania konkretnego nastawienia przez daną osobę) jest dostarczana pragmatycznie, to możemy budować spójną teorię nonkognitywistyczną. Takie rozwiązanie proponują hybrydowi ekspresywiści ${ }^{11}$. Zgodnie $\mathrm{z}$ takim ujęciem zawartość wartościująca jest implikowana w sensie P. Grice'a (Grice, 1975).

Brytyjski filozof Paul Grice zauważył, że ludzie poprzez swoje wypowiedzi chcą przekazać więcej niż tylko znaczenie słów, które wypowiadają. Rozważmy przykład: jeżeli A pyta B, czy jest głodny, a B odpowiada, że właśnie zjadł śniadanie, to B implikuje konwersacyjnie, że nie jest głodny, pomimo że takiej treści nie wypowiedział. Implikatura konwersacyjna to odrębny sąd logiczny od sądu rekonstruowanego na podstawie tego, co zostało wypowiedziane. Ponadto możliwa jest zarówno sytuacja, w której prawdziwy jest sąd rekonstruowany na podstawie tego, co zostało powiedziane, i fałszywa jest implikatura konwersacyjna, jak i sytuacja odwrotna (Grice, 1975). Treść implikatury konwersacyjnej jest rekonstruowana na podstawie czterech maksym konwersacyjnych i zasady współpracy. Zasada współpracy stanowi, że „wypowiedź powinna wnosić taki wkład, jakiego oczekuje się na danym etapie z punktu widzenia celu wymiany zdań, w której uczestniczysz" (Grice, 1975 za: Levinson, 2010, s. 116). Zasadę współpracy uszczegóławiają: maksyma jakości, ilości, istotności oraz sposobu (Levinson, 2010, s. 116; Grice, 1975).

\footnotetext{
${ }^{11}$ Ekspresywiści uznają istnienie własności moralnych, ale równocześnie zaprzeczają możliwości przypisania zdaniom zawierającym predykaty moralne wartości prawdy lub fałszu.
} 
Ponieważ treść implikatury nie wpływa na warunkowo-prawdziwościową zawartość wypowiedzianego zdania, możemy w spójny sposób używać języka moralnego. Rozważmy następujący przykład:

(I) Nawet filozofowie są nudni.

Zdanie (I) implikuje, że:

a) na subiektywnej skali prawdopodobieństwa (filozofowie są nudni) ma niższe prawdopodobieństwo niż ( $\mathrm{N}$ jest nudny) dla jakiegokolwiek $\mathrm{N}$ w kontekstowo zdeterminowanym zbiorze;

b) inni są nudni.

Warunki (a) i (b) nie są częścią warunków prawdziwości wypowiedzianego zdania (I). Jest tak ponieważ nawet jeśli implikatura jest fałszywa, to nie możemy powiedzieć, że:

(II) To nieprawda, że filozofowie są nudni.

Bowiem zgodnie z (I) filozofowie rzeczywiście są nudni, natomiast nie jest to mniej prawdopodobne niż nudność innych profesji (Bach, 2006; Barker, 2000).

Zatem dla hybrydowych ekspresywistów, takich jak Stephen Barker, „,chude pojęcia” (thin terms) zachowują się jak wyrażenia okazjonalne o konwencjonalnie implikowanym charakterze. Są one funkcją o argumentach w postaci nastawień i wartościach w postaci własności.

Kolejną kwestią jest charakter implikatury konwersacyjnej dla wyrażeń wartościujących. Niejasnym pozostaje, czy ma ona charakter konwencjonalny, czy konwersacyjny w sensie P. Grice'a. Implikatury konwencjonalne są, według Grice’a, wnioskowaniami

które nie mają charakteru warunkowo-prawdziwościowego, a także nie są wyprowadzalne na mocy szczególnych zasad pragmatycznych w rodzaju maksym konwersacyjnych. Są natomiast przypisane przez konwencję określonym wyrażeniom lub jednostkom językowym. Grice podaje tu tylko dwa przykłady: słowo „ale” [but] ma taką samą treść warunkowoprawdziwościową [...] jaką ma słowo „,i” [and] z tym dodatkiem, iż implikuje konwencjonalnie, że między członami jest kontrast. (Levinson, 2010, s. 146; por. Grice, 1975)

Sam status implikatury konwencjonalnej jest w literaturze kwestionowany. Wskazuje się, że jest ona raczej pragmatycznym wzbogaceniem sądu rekonstruowanego na podstawie wypowiedzi niż implikaturą konwersacyjną (Bach, 1999). Dodatkowo Stephen Finlay przedstawia dwa kontrargumenty przeciwko konwencjonalnej tezie Barkera. Po pierwsze, aby uzyskać własność, musimy najpierw zastosować funkcję. Zatem konieczna jest pierwotna chronologicznie znajomość nastawienia w celu poznania własności. W konsekwencji, aby zrekonstruować pełny sąd z wypowiedzi, potrzebujemy znajomości własności, którą uzyskujemy dzięki znajomości implikowanego nastawienia. W ten sposób warunki prawdziwości implikowanego sądu zaczynają być częścią warunków prawdziwości sądu rekonstruowanego za pomocą wypowiedzianego zdania. Powracamy do konkluzji, której chcieliśmy uniknąć. Na gruncie koncepcji P. Grice’a powinno być dokładnie odwrotnie znajomość warunków prawdziwości sądu rekonstruowanego z wypowiedzianego zdania 
powinna umożliwić znajomość warunków prawdziwości sądu implikowanego. Poza tym takie ujęcie nie pozwala na rozróżnienie własności moralnej i tego, co sprawia, że dane zjawisko ma taką, a nie inną własność. Rozważmy przykład:

(I) To rozwiązanie jest dobre.

Teoria, której poszukujemy, powinna nam wyjaśnić, dlaczego i z punktu widzenia jakich kryteriów mamy pozytywne nastawienie wobec czegoś, co jest dobre. Abstrakcyjna własność dobra nie jest praktycznie interesująca i jest ontologicznie podejrzana, co wykazują antyrealiści metaetyczni. Powinniśmy raczej poszukiwać kryteriów, zgodnie z którymi wyrażamy aprobujące nastawienie wobec własności. Innymi słowy, ciekawsze i przydatniejsze jest poszukiwanie takich kryteriów, które pozwalają nam uznać jakąś własność za dobrą.

W celu uniknięcia powyższych kontrargumentów i utrzymania spójności rozumowania można uznać zawartość wartościującą predykatów moralnych za implikaturę konwersacyjną. Dla uzasadnienia kryterialnego charakteru takich predykatów lepszą ich formalizacją wydaje się pojęcie relacji zamiast pojęcia funkcji. Taka teoria opiera się na kilku założeniach. Po pierwsze, moralne czy normatywne własności (z własnością bycia dobrym włącznie) są relacyjnymi własnościami. Po drugie, takie relacje występują pomiędzy pewną klasą obiektów, standardów, działań, stanów rzeczy itd., które posiadają taką własność. Po trzecie, wymienione obiekty w pewnym sensie spełniają lub nie relacyjne standardy. Wreszcie, przynajmniej niektórzy ludzie czasami są motywowani takimi standardami (Finlay, 2005, s. 9; Copp, 2006).

Hipotezę o konwersacyjnym charakterze zawartości wartościującej wydaje się potwierdzać struktura implikatury. Implikatury wartościujące są bowiem odwoływalne, to znaczy można im explicite zaprzeczyć. Stephen Finlay ilustruje takie stwierdzenie przypadkiem amoralisty, który w sposób szczery formułuje wypowiedzi z użyciem predykatów wartościujących, ale bez wyrażenia odpowiedniego nastawienia, niejako obojętnie. Zatem jeżeli audytorium ma świadomość, iż wypowiada się amoralista, lub amoralista sam wyjaśni, że nim jest, to implikowane wartościowanie zostanie odwołane, na przykład:

(I) To rozwiązanie jest niesłuszne, ale jestem amoralistą.

Konwersacyjne implikatury wartościujące nie są natomiast odrywalne, to znaczy użycie innego predykatu o podobnym znaczeniu nie powoduje ich zniknięcia:

(I) To rozwiązanie jest niesłuszne.

(II) To rozwiązanie jest niewłaściwe moralnie.

Ich struktura jest zatem analogiczna do struktury standardowej implikatury konwersacyjnej (Fletcher, 2015).

Podsumowując, podstawowy mechanizm hybrydowego ekspresywizmu opiera się na dwojakiej strukturze: sąd rekonstruowany na podstawie tego, co zostało wypowiedziane (czyli zdania), może być oceniany w kategoriach prawdy lub fałszu. Innymi słowy, treść zdania polega na przytoczeniu nastawienia. Natomiast sąd implikowany nie może być oceniany 
w kategoriach prawdy lub fałszu, ponieważ zawiera wyrażone nastawienie. Takie ujęcie wyjaśnia, dlaczego przytoczone wcześniej rozumowanie jest intuicyjnie prawdziwe:

(IV) Kłamstwo jest złe.

(V) Jan kłamie.

(VI) Jan postępuje źle.

Dzieje się tak dlatego, że prawdziwość rozumowania jest zachowana poprzez prawdziwość sądów rekonstruowanych na podstawie tego, co zostało wypowiedziane (zdania) zarówno w przesłankach, jak i wniosku. Są to sądy deskryptywne o nastawieniach wyrażanych przez mówców. Spór moralny toczy się natomiast o treść implikatury, czyli o to, jakie nastawienie należy w danym kontekście wyrazić. Takie ujęcie tłumaczy dwojaką kognitywną-nonkognitywną naturę nie tylko na poziomie sądu, ale także na poziomie predykatu takiego jak, na przykład, ,dobry”, czyli na poziomie tłustego pojęcia, które jest częściowo deskryptywne, a częściowo ewaluatywne, ponieważ wyraża nastawienie.

\section{Podsumowanie}

Sposób orzekania w oparciu o zasady dobra i słuszności oraz w oparciu o system norm zawierający lukę w praktyce przyjmuje uderzająco podobną postać praktycznego rozumowania oraz poszukiwania najlepszych racji dostępnych w kontekście. Ponadto orzekanie w oparciu o system zawierający lukę wymaga od decydenta wywiedzenia decyzji z przepisu, który rozważanego kontekstu sprawy nie przewiduje, co może rodzić konieczność sztucznej gimnastyki interpretacyjnej, możliwej do uniknięcia w ramach orzekania w oparciu o zasady dobra i słuszności. Co więcej, efektem takiej gimnastyki jest zazwyczaj zawoalowane sięganie po rację moralną, co powoduje, że rzeczywiste różnice metodologiczne pomiędzy ex aequo et bono oraz orzekaniem w trudnych przypadkach znikają.

Podobieństwa pomiędzy dwoma rodzajami orzekania są również widoczne na gruncie teoretycznym. W pracy wymienione i opisane zostały następujące podobieństwa teoretyczne: stosowanie racji moralnych, stosowanie metod orzekania w złożonych kontekstach, podważalność rozumowań (defeasibility), konieczność zaradzenia wadom języka naturalnego czy kontrowersje wokół pojęcia obiektywności orzekania. Jeżeli mamy trudności ze zdefiniowaniem obiektywności zarówno na gruncie orzekania w oparciu o przepisy prawa, jak i ex aequo et bono, to zarzut większego subiektywizmu czy relatywizmu kierowany wobec ex aequo et bono jest chybiony.

Wreszcie, teorią metaetyczną, która pozwala na stworzenie programu dla obiektywności epistemicznej orzekania ex aequo et bono, jest hybrydowy ekspresywizm. Zaletą ekspresywizmu są przede wszystkim ambitne cele, jakie sobie stawia jako program metaetyczny. Po pierwsze, wyjaśnia praktykę dyskursu moralnego bez proponowania rewizjonistycznych postulatów. Po drugie, dostarcza wyjaśnienia uporczywej niezgody moralnej, stojąc na stanowisku, że spieramy się o to, jakie nastawienia powinny być wyrażane w danym kontekście. Po trzecie, jest to teoria lekka ontologicznie, która poza relacją wyrażania nie 
postuluje metafizycznie podejrzanych faktów moralnych istniejących w świecie. Wreszcie hybrydowy ekspresywizm dostarcza wyjaśnienia dla intuicyjnej prawdziwości rozumowań zawierających przesłankę moralną.

\section{Bibliografia}

Bach, K. (1999). The myth of conventional implicature. Linguistics and Philosophy, 22, 327-366.

Bach, K. (2006). Top 10 misconceptions about implicature. W: L. R. Horn, B. J. Birner, G. L. Ward (red.), Drawing the boundaries of meaning: Neo-Gricean studies in pragmatics and semantics in honor of Laurence R. Horn. Amsterdam, Holandia: John Benjamins Publishing Company.

Barker, S. (2000). Is value content a component of conventional implicature? Analysis, 60, 268-279. https://doi.org/10.1093/analys/60.3.268

Blackburn, S. (1993). Essays in quasi-realism. New York, NY: Oxford University Press.

Blackburn, S. (2011). Antirealist expressivism and quasi-realism. W: D. Copp (red.), The Oxford handbook of ethical theory. Oxford, UK: Oxford Univervisty Press.

Brożek, B. (2008). Revisability versus defeasibility. Northern Ireland Legal Quarterly, 59, 139-147.

Copp, D. (2006). Realist expressivism and conventional implicature. W: R. Shafer-Landau (red.), Oxford studies in metaethics: Vol. 4 (s. 167-202). Oxford, UK: Oxford University Press.

Convention on the Settlement of Investment Disputes between States and Nationals of Other States, 1965, 17 UST 1270.

Dreier, J. (2004). Meta-ethics and the problem of creeping minimalism: Creeping minimalism. Philosophical Perspectives, 18, 23-44. https://doi.org/10.1111/j.1520-8583.2004.00019.x

Dyrda, A. (2013). Konwencja u podstaw prawa: Kontrowersje pozytywizmu prawniczego. Warszawa: Wolters Kluwer Polska.

European Convention for the Peaceful Settlement of Disputes, 1957, ETS No.023. Pobrano z: https://rm.coe.int/1680064586

Finlay, S. (2005). Value and implicature. Philosophers' Imprint, 5(4), 1-20.

Fletcher, G. (2014). Pure versus hybrid expressivism and the enigma of conventional implicature, W: G. Fletcher, M. Ridge (red.), Having it both ways: Hybrid theories and modern metaethics. New York, NY: Oxford University Press.

Fletcher, G. (2015). Moral utterances, attitude expression and implicature. W: G. Fletcher, M. Ridge (red.), Having it both ways: Hybrid theories and modern metaethics. New York, NY: Oxford University Press.

Gizbert-Studnicki, T. (2012). Consensus and objectivity of legal argumentation. W: M. Araszkiewicz (red.), Argumentation 2012: International Conference on Alternative Methods of Argumentation in Law: Conference proceedings (s. 1-13). Brno, Czechy: Masaryk University. 
Green, L. (2009). Legal positivism. W: E. N. Zalta (red.), The Stanford encyclopedia of philosophy (Fall 2009 edition). Pobrano z: https://plato.stanford.edu/archives/fall2009/entries/legal-positivism/

Grice, P. (1975). Logic and conversation. W: P. Cole, J. Morgan (red.), Syntax and semantics. New York, NY: Academic Press.

Hare, R. M. (2003). The language of morals. Oxford, UK: Clarendon Press.

Hart, H. L. A. (2012). The concept of law ( $3^{\text {rd }}$ ed.). Oxford, UK: Oxford University Press.

Hurka, T. (2015). Moore's moral philosophy. W: E. N. Zalta (red.), The Stanford encyclopedia of philosophy (Fall 2015 edition). Pobrano z: https://plato.stanford.edu/archives/fall2015/entries/mooremoral/

Jackson, F., Oppy, G., Smith, M. (1994). Minimalism and truth aptness. Mind, 103(411), 287-302.

Jackson, F., Petit, P. (1998). A problem for expressivism. Analysis, 58, 239-251.

Kirchin, S. (red.). (2013). Thick concepts. Oxford, UK: Oxford University Press.

Levinson, S. C. (2010). Pragmatyka. (T. Ciecierski, K. Stachowicz, thum.). Warszawa: Wydawnictwo Naukowe PWN. (Oryginalna praca opublikowana w 1983).

Marmor, A. (2016). Defeasibility and pragmatic indeterminacy in law. W: A. Capone, F. Poggi (red.), Pragmatics and law: Philosophical perspectives (s. 15-32). Dordrecht, Holandia: Springer.

Marmor, A., (2014). The language of law. Oxford, UK: Oxford University Press.

Moore, G. E. (2004). Principia ethica. Mineola, NY: Dover Publications.

Pichlak, M. (2017). Pozytywizm praktyczny, pozytywizm teoretyczny, pozytywizm żywy. Państwo i Prawo, 2017(5), 36-53.

Posłajko, K. (2017). Semantic deflationism, public language meaning, and contextual standards of correctness. Studia Semiotyczne, 31(1), 45-66.

Regulamin Arbitrażowy Międzynarodowej Izby Handlowej, 1 marca 2017, Pobrano z: https://cdn.iccwbo.org/content/uploads/sites/3/2017/03/ICC-2017-Arbitration-and-2014-Mediation-Rulespolish-version.pdf

Rodriguez-Blanco, V. (2014). Law and authority under the guise of the good: Law and practical reason. Oxford, UK: Hart Publishing.

Smith, M. (1994). Minimalism, truth-aptitude and belief. Analysis, 54(1), 21-26. https://doi.org/10.1093/analys/54.1.21

Statut Międzynarodowego Trybunału Sprawiedliwości, 1945, 59 Stat 1055, 1059.

Stoljar, D. (1993). Emotivism and truth conditions. Philosophical Studies, 70(1), 81-101. https://doi.org/10.1007/BF00989663

Trakman, L. (2008). Ex aequo et bono: Demystifying an ancient concept. Chicago Journal of International Law, 8(2), 621-642.

UNCITRAL Arbitration Rules, 2013, UN Doc. A/RES/31/98. Pobrano z: http://www.uncitral.org/pdf/english/texts/arbitration/arb-rules-2013/UNCITRAL-Arbitration-Rules-2013-e.pdf 
van Roojen, M. (2016). Moral cognitivism vs non-cognitivism. W: E. N. Zalta (red.), The Stanford encyclopedia of philosophy (Winter 2016 edition), Pobrane z: https://plato.stanford.edu/archives/win2016/entries/moral-cognitivism/

Wallace, R. J. (2014) Practical reason. W: E. N. Zalta (red.), The Stanford encyclopedia of philosophy (Summer 2014 edition), Pobrane z: http://plato.stanford.edu/archives/sum2014/entries/practical-reason/

Wronkowska, S., Zieliński, M. (1985). O korespondencji dyrektyw redagowania i interpretowania tekstu prawnego. Studia Prawnicze, 1985(3-4), 301-327.

\title{
Ex aequo et bono versus Hard Cases in the Light of Modern Metaethics
}

\begin{abstract}
In the present paper, I argue against the claim that ex aequo and bono adjudication cannot be epistemically objective. I start with a survey of legal rules allowing the parties to resort to ex aequo et bono adjudication. Next, I argue that decisions taken on ex aequo et bono basis are not subjective for three main reasons. First, they are analogous to decision making in hard cases. Second, theories of practical reasoning and hybrid expressivism provide a precise theoretical account of the mechanisms at stake. Third, the context of adjudication provides substantial constraints on judicial tasks.
\end{abstract}

Keywords: ex aequo et bono; hybrid expressivism; practical reasoning; ethical judgement; inclusive legal positivism; context. 